\title{
Article \\ Changes in Volatile Compounds and Quality Characteristics of Salted Shrimp Paste Stored in Different Packaging Containers
}

\author{
Jaksuma Pongsetkul $^{1, *(\mathbb{D}}$, Soottawat Benjakul ${ }^{2} \mathbb{D}$ and Pakpoom Boonchuen ${ }^{3}$ \\ 1 School of Animal Technology and Innovation, Institute of Agricultural Technology, \\ Suranaree University of Technology, Nakhon Ratchasima 30000, Thailand \\ 2 International Center of Excellence in Seafood Science and Innovation, Faculty of Agro-Industry, \\ Prince of Songkla University, Songkhla 90110, Thailand; soottawat.b@psu.ac.th \\ 3 School of Biotechnology, Institute of Agricultural Technology, Suranaree University of Technology, \\ Nakhon Ratchasima 30000, Thailand; pakpoom.b@sut.ac.th \\ * Correspondence: jaksuma@sut.ac.th; Tel.: +66-44-223641
}

Citation: Pongsetkul, J.; Benjakul, S.; Boonchuen, P. Changes in Volatile Compounds and Quality Characteristics of Salted Shrimp

Paste Stored in Different Packaging Containers. Fermentation 2022, 8, 69 https://doi.org/10.3390/ fermentation 8020069

Academic Editor: Bernard Chen

Received: 14 January 2022

Accepted: 5 February 2022

Published: 7 February 2022

Publisher's Note: MDPI stays neutral with regard to jurisdictional claims in published maps and institutional affiliations.

Copyright: (C) 2022 by the authors. Licensee MDPI, Basel, Switzerland. This article is an open access article distributed under the terms and conditions of the Creative Commons Attribution (CC BY) license (https:// creativecommons.org/licenses/by/ $4.0 /)$.

\begin{abstract}
Quality changes of salted shrimp paste, one of the most popular traditional Thai fermented food ingredients, stored in different packaging containers including polypropylene containers (PP), polyethylene terephthalate containers (PET), glass jar containers (GJ) as well as LLDPE/Nylon vacuum bags (VB) at room temperature $\left(28 \pm 1{ }^{\circ} \mathrm{C}\right)$ for 15 months were studied. The relationship between quality attributes (i.e., volatiles, browning index $\left(\mathrm{A}_{420}\right)$, biogenic amines, TBARS) and consumer acceptability as indicated by sensory scores were also investigated using principal component analysis (PCA). During storage, some desirable quality characteristics of shrimp paste were improved as indicated by the higher sensory scores of all samples when stored for 6 months, compared with the sample at day $0(p \leq 0.05)$. However, further changes in all compositions when extended storage time can conversely diminish those desirable characteristics and led to lowering consumers' acceptability. In this study, GJ seem to be the most potential packaging for preserving original products' quality during storage for this product since it exhibited the lower rate of quality changing than others throughout the storage. Conversely, VB exhibited unique volatiles and microbial profiles, compared with others, which led to the lowest sensory scores at all period test $(p \leq 0.05)$, implying that vacuum conditions may not be suitable for the storage of this product. Moreover, based on PCA results, the intensity of nitrogen-containing compounds correlated well with sensory acceptability, particularly flavor-likeness. Our study provides useful knowledge for understanding the different quality characteristics, particularly flavors, associated with different packaging containers during prolonged storage of salted shrimp paste.
\end{abstract}

Keywords: salted shrimp paste; packaging; storage; volatiles; biogenic amines; fermented shrimp paste

\section{Introduction}

Salted shrimp paste is the most popular condiment with salty and umami taste used for enhancing the palatability of countless local Southeast-Asian dishes. It is known as kapi in Thailand, belacan in Malaysia, ngapi in Burma, terasi in Indonesia, or andaramang in Philippine, and so forth [1]. In Thailand, salted shrimp paste is made by the fermentation of small shrimp (Acetes vulgaris) with salt at a ratio of 5:1 (shrimp to salt, $w / w$ ) for at least 1 month or until the unique flavor/typical aroma is developed [2]. During fermentation, the transformation of organic substances into simpler compounds such as peptides, amino acids, aldehydes, organic acids, amines and other nitrogenous compounds, either by the action of microorganisms or endogenous enzymes, takes place. These compounds are important contributors to the flavor and aroma of products [2]. Normally, salted shrimp paste is classified as an intermediate moisture food (IMF), having water activity $\left(\mathrm{a}_{\mathrm{w}}\right)$ of about $0.65-0.70$ [3]; thus it could be preserved for several months. However, experienced consumers who consumed salted shrimp paste regularly stated that although salted shrimp 
paste can be kept at room temperature for at least 3 months, some quality loss occurs during the storage period, especially flavor and odor. During storage, further changes in microbiological and biochemical, particularly protein and lipid degradation may occur, resulting in quality losses. Generally, the rate of alteration of fermented products depends on several factors such as types of ingredients, manufacturing process, hygiene of processing, microbial loads, type of packaging and how the food is stored [4]. Nowadays, no information regarding the quality changes of salted shrimp paste during storage exists. Additionally, suitable packaging for this product has been searched for. Nowadays, this product is popularly packed into plastic container, particularly polyethylene (PP) or polyethylene terephthalate (PET), because of its cheap and high availability. Although there is a standard for fermented products in Thailand, the awareness of food safety is still limited. Salted shrimp paste is generally not labelled with a suggested shelf-life and is usually stored at room temperature until they are completely consumed. Ali et al. [5] reported that general shrimp paste contains several volatiles, that is, hydrocarbons, carbonyls, sulphur, alcohols, nitrogen, and esters. These compounds are keys of desirable odor and flavor of shrimp paste product. An appropriate packaging material and system which offers high barrier properties can prevent gas permeations. Moreover, oxidation of lipids may further improve the quality of shrimp paste during storage. Thus, shrimp paste packaging seems to play a profound role in prolonging shelf-life or in maintaining its prime quality, especially flavor development. Therefore, this study aims to evaluate quality changes of salted shrimp paste stored in different packaging containers during storage for 15 months, which may diminish their shelf-life. The sample quality during storage was also carefully compared with Thailand standard specification [6] of this product to ensure their safety for human consumption.

\section{Materials and Methods}

\subsection{Preparation of Salted Shrimp Paste}

Twenty-five $\mathrm{kg}$ of fresh tiny shrimp (Acetes vulgaris) (average body length: $13.2 \pm 1.8 \mathrm{~mm}$; average weight: $38.2 \pm 9.0 \mathrm{mg}, \mathrm{n}=20$ ), were obtained from a local market in Ra-yong, Thailand. Shrimp were transported directly to the laboratory in a polystyrene box containing ice using a shrimp/ice ratio of 1:2 (w/w) within approximately $1 \mathrm{~h}$. Upon arrival, shrimp were washed twice with $3 \% \mathrm{NaCl}(w / v)$ solution, drained and mixed with solar salt at a shrimp/salt ratio of 5:1 $(w / w)$. The mixture was transferred to the polypropylene basket, covered with cheese cloth and allowed to salt at room temperature $\left(28-30{ }^{\circ} \mathrm{C}\right)$ overnight. The salted shrimp was drained, ground into a uniform paste using a blender (National, Tokyo, Japan), spread out on fiberglass mats, and then allowed to dry under sunlight until the moisture content decreased to the range of 35-40\% [7]. Subsequently, dried shrimp were compacted into earthen jars, covered with a plastic bag tightly (close system) and fermentation was proceeded at room temperature $\left(28-30^{\circ} \mathrm{C}\right)$ for 30 days. After fermentation, the sample was collected for further analyses.

\subsection{Characterization of Salted Shrimp Paste Quality}

\subsubsection{Water Activity $\left(\mathrm{a}_{\mathrm{w}}\right), \mathrm{pH}$ and Color}

Water activity $\left(\mathrm{a}_{\mathrm{w}}\right)$ was determined using the water activity analyzer (Thermoconstanter, Novasina, Switzerland). For $\mathrm{pH}$ measurement, $10 \mathrm{~g}$ of the sample were mixed with $100 \mathrm{~mL}$ of distilled water and then measured by using a pH meter (Sartorius, Gottingen, Germany). Color of the ground sample was measured using an automatic colorimeter (ColourFlex, Hunter Lab Reston, Reston, VA, USA) and was expressed as $L^{*}$ (lightness), $a^{*}$ (redness/greenness), and $b^{*}$ (yellowness/blueness).

\subsubsection{Browning Intensity}

Browning intensity $\left(\mathrm{A}_{420}\right)$ was measured according to Pongsetkul et al. [2]. One gram of sample was diluted with $25 \mathrm{~mL}$ of distilled water and homogenized at a speed of $10,000 \times g$ for 2 min using an IKA Labortechnik homogenizer (Selangor, Malaysia). The homogenates 
were then centrifuged at $10,000 \times g$ for $15 \mathrm{~min}$ at room temperature. Absorbance of supernatant was read at $420 \mathrm{~nm}$ using the UV-1601 spectrometer.

\subsubsection{Thiobarbituric Acid Reactive Substances (TBARS) Value}

The TBARS value was measured following the method of Nirmal and Benjakul [8]. A standard curve was prepared by using malonaldehyde bis (dimethyl acetal) at concentration range of $0-2 \mathrm{ppm}$. TBARS value was calculated and expressed as mg malonaldehyde (MDA)/kg sample.

\subsubsection{Amino Nitrogen Content}

Amino nitrogen content was detected by formaldehyde potentiometric titration following the method of Che et al. [9] with slight modification. Two grams of sample was dissolved in $50 \mathrm{~mL}$ of distilled water, then filtered with Whatman No. 1 filter paper (Whatman, Maidstone, UK). The filtrates were adjusted to $50 \mathrm{~mL}$ of distilled water. Then, $2 \mathrm{~mL}$ of sample solution was added with $4 \mathrm{~mL}$ of ammonium acetate buffer solution and $4 \mathrm{~mL}$ of color reagent, mixed together and then boiled for $15 \mathrm{~min}$. (Formaldehyde $(15 \mathrm{~mL}, 38 \%$ ) and acetylacetone $(7.8 \mathrm{~mL})$ were mixed to $100 \mathrm{~mL}$ to prepare color reagent). After cooling to ambient temperature, the absorbance was measured at $400 \mathrm{~nm}$ using a microplate reader (FLUOstar Omega, BMG Labtech Multi-mode microplate reader, Ortenberg, Germany).

\subsubsection{Inorganic Contaminants}

Inorganic contaminants including arsenic $(\mathrm{As})$, cadmium $(\mathrm{Cd})$, lead $(\mathrm{Pb})$ and mercury $(\mathrm{Hg})$ were measured using acid digestion and quantification by ICP-OES (inductively coupled plasma-optical emission spectrometry). In this experiment, the Vista e MPX CCD Simultaneous ICP-OES equipped with axial vision, a radio frequency (RF) source of $40 \mathrm{MHz}$, a CCD (Charge Coupled Device)-type simultaneous multi-elementary solid-state detector, a peristaltic pump, a nebulization chamber, and a sea spray nebulizer were used. The system was controlled by ICP-Expert software using liquid argon as plasma gas with 99.996\% purity (Air Liquid, SP, Brazil). The experimental conditions used followed the method of Morgano et al. [10] and expressed as $\mathrm{mg} / \mathrm{kg}$ sample.

\subsubsection{Microbial Loads}

Total viable count (TVC), Yeast and Mold count, lactic acid bacteria (LAB) as well as some pathogenic bacteria including Salmonella spp., Staphylococcus aureus, Bacillus cereus, Clostridium perfringens and Escherichia coli were analyzed followed the method of BAM [11] and Thai Community Product Standards [6]. Salted shrimp paste $(25 \mathrm{~g})$ was mixed with $225 \mathrm{~mL}$ of $0.1 \%$ peptone water containing $10 \%(w / v) \mathrm{NaCl}$ in a Stomacher $400 \mathrm{Lab}$ Blender (Seward Ltd., Worthing, UK) at high speed for $3 \mathrm{~min}$. The samples, with appropriate serial tenfold dilution, were cultivated in each specific media (Xylose lysine desoxycholate (XLD) agar for Salmonella spp., Trypticase (triptic) soy agar (TSA) for S. aureus, mannitol egg yolk polymixin agar (MYP, Difco, (Darmstadt, Germany) for B. cereus, Tryptose-sulfitecycloserine (TSC) agar for C. perfringens, as well as Levine's eosin-methylene blue (L-EMB) agar for E. Coli) and incubated following the procedure of individuals. Then, microbial population were counted and reported as colony forming units (CFU)/g sample.

\subsubsection{Volatile Compounds}

Volatile compounds of samples were determined using a solid-phase microextraction gas chromatography mass spectrometry (SPME GC-MS) as described by Pongsetkul et al. [2]. Five grams of salted shrimp paste were mixed with $10 \mathrm{~mL}$ of distilled water and homogenized at $11,000 \times g$ for $1 \mathrm{~min}$ to disperse the sample. The homogenate was placed in a 20-mL headspace vial (Supelco, Bellefonte, PA, USA). The vials were tightly capped with a PTFE septum and heated at $60^{\circ} \mathrm{C}$ with equilibrium time of $10 \mathrm{~h}$. The SPME fiber (50/30 lm DVB/Carboxen ${ }^{\mathrm{TM}} /$ PDMS StableFlex ${ }^{\mathrm{TM}}$ ) (Supelco, Bellefonte, PA, USA) was conditioned at $270{ }^{\circ} \mathrm{C}$ for $15 \mathrm{~min}$ before use and exposed to the headspace. The sample 
extract was then desorbed in the GC injector port for $15 \mathrm{~min}$ at $270{ }^{\circ} \mathrm{C}$. GC-MS analysis was performed in a HP 5890 series II gas chromatography (GC) coupled with HP 5972 mass-selective detector equipped with a splitless injector and coupled with a quadrupole mass detector (Hewlett Packard, Atlanta, GA, USA). The identified volatile compounds were expressed in the terms of relative abundance.

\subsubsection{Biogenic Amines (BAs)}

Eight common BAs including tryptamine (Try), $\beta$-phenethylamine (Phe), putrescine (Put), cadaverine (Cad), histamine (His), tyramine (Tyr), spermine (Spm), and spermidine (Spd) were determined following the method of Sang et al. [12] with slight modification. Five grams of salted shrimp paste was mixed with $20 \mathrm{~mL}$ of $10 \%$ trichloroacetic acid (TCA), homogenized at $11,000 \times g$ for $1 \mathrm{~min}$ to disperse the sample and allowed to stand at $4{ }^{\circ} \mathrm{C}$ for $2 \mathrm{~h}$. After that, the mixture was centrifuged at $8500 \times g$ for $10 \mathrm{~min}\left(4^{\circ} \mathrm{C}\right)$. The supernatant was collected whereas the residue was re-extracted with an equal volume of $10 \%$ TCA with the same condition. All supernatants were combined and adjusted the final volume to $50 \mathrm{~mL}$ with $10 \%$ TCA. After filtered through a $0.22 \mu \mathrm{m}$ pore-size filter, $1 \mathrm{~mL}$ of the extract was mixed with $200 \mu \mathrm{L}$ of $2 \mathrm{M}$ sodium hydroxide and $300 \mu \mathrm{L}$ of saturated sodium bicarbonate. Then, $2 \mathrm{~mL}$ of dansyl chloride solution $(10 \mathrm{mg} / \mathrm{mL})$ prepared in acetone was added and the mixture was incubated at $45^{\circ} \mathrm{C}$ for $40 \mathrm{~min}$. The residual dansyl chloride was removed by adding $125 \mu \mathrm{L}$ of ammonia followed by further incubation at room temperature for $30 \mathrm{~min}$. After that, the volume was adjusted with acetonitrile to a final volume of $5 \mathrm{~mL}$. Finally, the mixture was centrifuged at $3000 \times g$ for $5 \mathrm{~min}$, and the supernatant was filtered twice through a $0.22-\mu \mathrm{m}$ filter. The filtered supernatant was kept at $-80^{\circ} \mathrm{C}$ for subsequent HPLC analysis. For HPLC determination, an Alliance $2690 \mathrm{HPLC}$ unit (Agilent, Palo Alto, CA, USA), which consisted of a Sulfire-C18 column $(4.6 \times 200 \mathrm{~mm}$, $5 \mu \mathrm{m})$ coupled to a quaternary pump and a diode array detector at the wavelength of $254 \mathrm{~nm}$. The results were calculated using an external standard method of peak area and expressed as $\mathrm{mg} / \mathrm{kg}$ sample.

\subsubsection{Sensory Evaluation}

The 50 untrained panelists, who are familiar with salted shrimp paste, were asked to assess samples for appearance-liking, color-liking, flavor-liking, texture-liking, and overall-liking scores using a 9-point hedonic scale ( 1 = dislike extremely, $9=$ like extremely). For sample preparation, salted shrimp paste were wrapped with aluminum foil and heated in hot air oven at $60{ }^{\circ} \mathrm{C}$ for $30 \mathrm{~min}$. After cutting into small pieces $\left(2 \times 2 \times 1 \mathrm{~cm}^{2}\right)$, samples were placed in 15-mL plastic cup, covered with lids and left at room temperature for $30 \mathrm{~min}$ before serving. Evaluation was performed in individual sensory evaluation booths under fluorescent white light. The sample was presented in three-digit codes. The panelists were asked to open the lid, sniff and further taste the sample. A piece of plain cracker and a glass of warm water were provided for panelists to rinse their mouth between each sample.

\subsection{Study on the Quality Changes of Salted Shrimp Paste Stored in Different Packaging Containers during Storage}

To study the quality changes during storage, $200 \mathrm{~g}$ of salted shrimp paste was packed in 4 different packaging containers including:

(1) Polypropylene container $(6.5 \times 7.0 \mathrm{~cm})$ with plastic lid $(\mathrm{PP})$;

(2) Polyethylene terephthalate container $(7.0 \times 8.5 \mathrm{~cm})$ with plastic lid $(\mathrm{PET})$;

(3) Glass jar container $(6.0 \times 7.0 \mathrm{~cm})$ with plastic lid $(\mathrm{GJ})$;

(4) LLDPE/Nylon vacuum bag $(15 \times 25 \mathrm{~cm})(\mathrm{VB}) *$.

* The last sample was kept in the vacuum condition (no air).

Each sample were kept at room/ambient temperature $\left(28 \pm 1{ }^{\circ} \mathrm{C}\right)$ for 15 months. Samples were taken every 3 months for physical, chemical and microbial analysis; this was the same with Section 2.2, except the determination of volatile compounds, biogenic amines and sensory evaluation were done only on the 6th and 12th months of storage. 
While inorganic contaminants as well as pathogenic bacteria were evaluated on the final day of storage (15th month) to confirm the food safety of this product as per the Thai Community Product Standard No. TCPS 61/2018 [6]. Moreover, principal component analysis (PCA) was performed to assess the relationship between quality attributes and sensory scores of salted shrimp paste stored in different packaging containers during storage for 6 and 12 months.

\subsection{Statistical Analysis}

All analyses were conducted in triplicate. Results were reported as mean values \pm standard error. Statistical analysis was performed using two-way analysis of variance (ANOVA). Mean comparison was carried out using Duncan's multiple range test (DMRT) at the significance level of 95\% ( $p \leq 0.05)$. SPSS statistic program (Version 16.0) (SPSS for window, SPSS Inc., Chicago, IL, USA) was used for data analysis.

\section{Results and Discussion}

\subsection{Quality Characteristics of Salted Shrimp Paste}

Physical, chemical properties and microbial populations of salted shrimp paste (at day 0 /before storage) is shown in Table 1 . Water activity $\left(a_{w}\right)$ of this product was 0.68 , thus it can be classified as an intermediate moisture food since it was in the range of 0.6-0.7 [13]. This was associated with the prolonged shelf-life of this product due to the lowered growth of both pathogenic and spoilage microorganisms [14]. However, the $\mathrm{a}_{\mathrm{w}}$ can be varied depending on the duration of salting or drying process. The $\mathrm{pH}$ value of salted shrimp paste was 7.05, which similar as reported by many previous studies. Pongsetkul et al. [3] revealed that $\mathrm{pH}$ of various Thai salted shrimp paste was 7.01-8.40. While the $\mathrm{pH}$ of Korean and Indonesian shrimp paste was in the range of 6.83-7.23 and 6.40-7.57, respectively $[15,16]$.

Table 1. Physical, chemical properties and microbial populations of salted shrimp paste (at day $0 /$ before storage).

\begin{tabular}{llll}
\hline Parameters & Values & Parameters & Values \\
\hline Water activity $\left(\mathrm{a}_{\mathrm{w}}\right)$ & $0.68 \pm 0.01$ & Microbial population & \\
$\mathrm{pH}$ & $7.05 \pm 0.13$ & Total viable count (TVC) & $4.51 \pm 0.78 \mathrm{log}$ CFU $/ \mathrm{g}$ \\
Color & & Yeast \& Mold & $0.65 \pm 0.08 \mathrm{log}$ CFU $/ \mathrm{g}$ \\
$L^{*}$ & $44.39 \pm 1.32$ & Lactic acid bacteria (LAB) & $2.07 \pm 0.45 \mathrm{log}$ CFU $/ \mathrm{g}$ \\
$a^{*}$ & $8.66 \pm 0.88$ & Salmonella spp. & $\mathrm{ND}$ \\
$b^{*}$ & $26.75 \pm 1.15$ & S. aureus & $<10 \mathrm{CFU} / \mathrm{g}$ \\
Browning intensity $\left(\mathrm{A}_{420}\right)$ & $0.38 \pm 0.09$ & B. cereus & $<10$ CFU $/ \mathrm{g}$ \\
TBARS value $(\mathrm{mg}$ MDA $/ \mathrm{kg})$ & $0.76 \pm 0.07$ & C. perfringens & $\mathrm{ND}$ \\
Amino nitrogen content $(\mathrm{g} / 100 \mathrm{~g})$ & $0.63 \pm 0.06$ & E. coli & $16 \mathrm{CFU} / \mathrm{g}$ \\
Inorganic contaminants & & & \\
Pb $(\mathrm{mg} / \mathrm{kg})$ & $\mathrm{ND}$ & & \\
$\mathrm{As}(\mathrm{mg} / \mathrm{kg})$ & $\mathrm{ND}$ & & \\
$\mathrm{Hg}(\mathrm{mg} / \mathrm{kg})$ & $0.15 \pm 0.04$ & & \\
$\mathrm{Cd}(\mathrm{mg} / \mathrm{kg})$ & $0.22 \pm 0.08$ & & \\
\hline
\end{tabular}

Values are the mean of three replications \pm standard deviation. ${ }^{*}$ ND: Not detectable.

Salted shrimp paste had $L^{*}, a^{*}$ and $b^{*}$ of $44.39,8.66$ and 26.75 , respectively. Normally, the color of salted shrimp paste varies from a pinkish or purplish gray to a dark grayish brown [1]. This parameter seems to be important since it affects consumer purchase decisions. The slightly higher in $b^{*}$-value or yellowness was in agreement with the browning intensity $\left(\mathrm{A}_{420}\right)$ of 0.38 (Table 1 ), which indicated that our sample is dominated by the brown color. TBARS value of salted shrimp paste at day 0 was $0.76 \mathrm{mg}$ MDA $/ \mathrm{kg}$ sample suggesting that lipid oxidation was enhanced during processing, particularly at the fermentation period. TBARS value is referred to the secondary reaction products of lipid oxidation, which normally responsible for shrimp paste flavor [17]. Amino nitrogen content was counted and reported as $0.63 \mathrm{~g} / 100 \mathrm{~g}$ sample, indicating that protein or polypeptide 
decomposition/degradation was occurred during processing/fermentation [3]. However, these physical and chemical characteristics of this product may different since it was intensively governed by each processing method.

For microbial populations, salted shrimp paste had the amount of total viable count (TVC) and lactic acid bacteria count (LAB) of 4.51 and $2.07 \log$ CFU/g sample, respectively (Table 1). Normally, microorganism in fermented foods is in the range of 5.00-8.00 log $\mathrm{CFU} / \mathrm{g}$ sample [18]. For this product, the presence of LAB but not dominant was stated as reported by Pongsetkul et al. [19] and Nakamura et al. [20]. Moreover, the amount of yeast and mold count, accountable for $0.65 \mathrm{log}$ CFU/g sample, was in the range of the standard, which is regulated as not more than $3.00 \log$ CFU/g sample [6], while all pathogens including Salmonella spp., S. aureus, B. cereus, C. perfringens and E. coli were found below the standard limit [6]. Thus, the microbial profiles, in addition to the absence of $\mathrm{Pb}$ and As, as well as the presence at the lower amount restricted by the standard of $\mathrm{Hg}$ and $\mathrm{Pd}$, which are major hazards found in this product, can be assured that this salted shrimp paste was of a quality under the standard and is safe to consume.

\subsection{Quality Changes of Salted Shrimp Paste Stored in Different Packaging Containers during Storage}

\subsubsection{Changes in $\mathrm{a}_{\mathrm{w}}, \mathrm{pH}$ and Color}

The continuous increase in $\mathrm{a}_{\mathrm{w}}$ as storage time increased was observed in all samples $(p \leq 0.05)$, from 0.68 to $0.76-0.83$, when stored up to 15 months as shown in Table 2 . In the first 3 months, there was no difference in $\mathrm{a}_{\mathrm{w}}$ among all samples $(p>0.05)$. Then, it was observed that the higher rate of the increase in $a_{w}$ was noted in VB, followed by PET, compared with PP and GJ ( $p \leq 0.05)$. These may be associated with the different water permeability of each packaging material. Robertson [21] stated that glass is an ideal packaging material since it is inert and resistant to any hazards. Glass is a total barrier against gases and vapor, because of its inorganic chemical composition which does not allow any diffusion of molecules. Among plastic types, Massey [22] reported that the water permeability of Nylon6 and LLDPE (material for VB) at room temperature was 6-22 and 1.0-1.5 g/100 sq. inch/day, respectively, which was higher than PP, accountable for $0.2-0.5 \mathrm{~g} / 100 \mathrm{sq}$. inch/day. The higher water permeability could favor moisture migration from the environment through the packaging, resulting in the increase in moisture content or $\mathrm{a}_{\mathrm{w}}$ of the product. Normally, $\mathrm{a}_{\mathrm{w}}$ is associated with the prolonged shelf-life of the product as it is related with the rate of all chemical and microbiological actions during storage [14]. However, $\mathrm{a}_{\mathrm{w}}$ of all samples were lower than 0.85 , therefore, still meets the quality requirements of this product as regulated by TCPS [6] even stored for 15 months. The gradually increase in $\mathrm{pH}$ of all samples were found when extended the storage time $(p \leq 0.05)$ (Table 2). The increase of $\mathrm{pH}$ during storage was plausibly related with the formation of degradation products or volatile base compounds, that is, ammonia produced by endogenous or microbial enzymes [19]. Among all samples, PP had the highest $\mathrm{pH}$ at all period tests $(p \leq 0.05)$ and reached 7.49 when stored for 15 months. In contrast, VB exhibited the slowest rate of the increase in $\mathrm{pH}$ throughout the storage. This may be associated with the vacuum condition (no air) of VB may accelerate the growth of lactic acid bacteria (LAB) surviving in salted shrimp paste. These LAB can produce acids, thus resulting in suppress the increase in $\mathrm{pH}$ during storage. This reason was in agreement well with the higher in LAB of VB at all period tests, compared with others $(p \leq 0.05)$ as shown in Figure 1F.

Table 2. Changes in water activity $\left(\mathrm{a}_{\mathrm{w}}\right), \mathrm{pH}$ and color of salted shrimp paste stored in various packaging container at room temperature $\left(28 \pm 1^{\circ} \mathrm{C}\right)$.

\begin{tabular}{cccccc}
\hline Parameters & Month of Storage & PP & PET & GJ & VB \\
\hline \multirow{2}{*}{ Water activity $\left(\mathrm{a}_{\mathrm{w}}\right)$} & 3 & $0.70 \pm 0.01^{\mathrm{c}}$ & $0.71 \pm 0.01^{\mathrm{d}}$ & $0.70 \pm 0.01^{\mathrm{b}}$ & $0.70 \pm 0.02^{\mathrm{d}}$ \\
& 6 & $0.72 \pm 0.02^{\mathrm{Bb}}$ & $0.74 \pm 0.02^{\mathrm{Ac}}$ & $0.71^{\mathrm{Bb}} \pm 0.01^{\mathrm{Bb}}$ & $0.75 \pm 0.02^{\mathrm{Ac}}$ \\
& 9 & $0.73 \pm 0.01^{\mathrm{Bb}}$ & $0.77 \pm 0.01^{\mathrm{Ab}}$ & $0.73 \pm 0.02^{\mathrm{Ba}}$ & $0.73^{\mathrm{Ab}} \pm 0.01^{\mathrm{Ab}}$ \\
\hline
\end{tabular}


Table 2. Cont.

\begin{tabular}{|c|c|c|c|c|c|}
\hline Parameters & Month of Storage & $\mathbf{P P}$ & PET & GJ & VB \\
\hline & 12 & $0.77 \pm 0.02 \mathrm{Ba}$ & $0.80 \pm 0.02 \mathrm{Aa}$ & $0.74 \pm 0.02 \mathrm{Ca}$ & $0.81 \pm 0.02 \mathrm{Aa}$ \\
\hline & 15 & $0.78 \pm 0.02 \mathrm{Ca}$ & $0.81 \pm 0.01 \mathrm{Ba}$ & $0.76 \pm 0.02 \mathrm{Ca}$ & $0.83 \pm 0.01 \mathrm{Aa}$ \\
\hline \multirow{5}{*}{$\mathrm{pH}$} & 3 & $7.18 \pm 0.03 \mathrm{Ad}$ & $7.09 \pm 0.06^{\mathrm{Bd}}$ & $7.10 \pm 0.05^{\mathrm{Bc}}$ & $7.10 \pm 0.02 \mathrm{Bb}$ \\
\hline & 6 & $7.26 \pm 0.06 \mathrm{Ac}$ & $7.13 \pm 0.04 \mathrm{Cd}$ & $7.16 \pm 0.02 \mathrm{Bb}$ & $7.20 \pm 0.06^{\mathrm{Ba}}$ \\
\hline & 9 & $7.30 \pm 0.03 \mathrm{Ac}$ & $7.20 \pm 0.02 \mathrm{Bc}$ & $7.20 \pm 0.07 \mathrm{Bb}$ & $7.24 \pm 0.04 \mathrm{Ba}$ \\
\hline & 12 & $7.42 \pm 0.04 \mathrm{Ab}$ & $7.29 \pm 0.03 \mathrm{Bb}$ & $7.23 \pm 0.02 \mathrm{Cb}$ & $7.28 \pm 0.02 \mathrm{Ba}$ \\
\hline & 15 & $7.49 \pm 0.03 \mathrm{Aa}$ & $7.34 \pm 0.05^{\mathrm{Ba}}$ & $7.31 \pm 0.04 \mathrm{Ba}$ & $7.26 \pm 0.02 \mathrm{Ca}$ \\
\hline \multirow{5}{*}{ Lightness $\left(L^{*}\right)$} & 3 & $39.99 \pm 1.55 \mathrm{Ba}$ & $41.45 \pm 1.92 \mathrm{Ba}$ & $43.22 \pm 1.03 \mathrm{Aa}$ & $45.03 \pm 3.05 \mathrm{Aa}$ \\
\hline & 6 & $40.05 \pm 2.03^{\mathrm{Aa}}$ & $37.13 \pm 3.06^{\mathrm{Bb}}$ & $42.01 \pm 1.98^{\mathrm{Aab}}$ & $40.62 \pm 2.01 \mathrm{Ab}$ \\
\hline & 9 & $36.66 \pm 2.61^{\mathrm{Bb}}$ & $37.05 \pm 1.44^{\mathrm{Bb}}$ & $40.66 \pm 2.05^{\mathrm{Ab}}$ & $39.04 \pm 2.22 \mathrm{Ab}$ \\
\hline & 12 & $33.28 \pm 2.15^{\mathrm{Bb}}$ & $32.22 \pm 2.04^{\mathrm{Bc}}$ & $35.82 \pm 1.56$ Ac & $35.13 \pm 1.69 \mathrm{Ac}$ \\
\hline & 15 & $34.49 \pm 1.98^{b}$ & $32.91 \pm 2.09^{c}$ & $35.10 \pm 1.71^{\mathrm{c}}$ & $34.02 \pm 2.23^{c}$ \\
\hline \multirow{5}{*}{ Redness/greenness $\left(a^{*}\right)$} & 3 & $8.01 \pm 0.66$ & $8.25 \pm 0.55$ & $7.93 \pm 0.81$ & $8.25 \pm 0.49$ \\
\hline & 6 & $8.22 \pm 0.43$ & $8.43 \pm 0.34$ & $8.20 \pm 1.01$ & $8.40 \pm 0.47$ \\
\hline & 9 & $8.16 \pm 0.31$ & $8.33 \pm 0.45$ & $8.21 \pm 0.55$ & $8.21 \pm 0.88$ \\
\hline & 12 & $8.53 \pm 0.37$ & $8.69 \pm 0.29$ & $8.32 \pm 0.29$ & $8.40 \pm 0.20$ \\
\hline & 15 & $9.02 \pm 0.63$ & $8.98 \pm 0.42$ & $8.39 \pm 0.62$ & $8.11 \pm 0.52$ \\
\hline \multirow{5}{*}{ Yellowness / blueness $\left(b^{*}\right)$} & 3 & $25.23 \pm 1.03^{\mathrm{a}}$ & $25.02 \pm 0.89^{a}$ & $26.82 \pm 1.01^{\mathrm{a}}$ & $24.42 \pm 1.24^{\mathrm{a}}$ \\
\hline & 6 & $24.26 \pm 1.21 \mathrm{Aa}$ & $24.11 \pm 1.01 \mathrm{Aa}$ & $24.02 \pm 1.02 \mathrm{Aab}$ & $22.55 \pm 0.88^{\mathrm{Bab}}$ \\
\hline & 9 & $22.88 \pm 0.99 \mathrm{Bb}$ & $20.45 \pm 1.02 \mathrm{Cb}$ & $24.55 \pm 1.13 \mathrm{Aab}$ & $22.81 \pm 1.06^{\mathrm{Bab}}$ \\
\hline & 12 & $19.43 \pm 1.01 \mathrm{Bb}$ & $21.66 \pm 1.15^{\mathrm{Bb}}$ & $23.02 \pm 0.67^{\mathrm{Ab}}$ & $20.01 \pm 0.82^{\mathrm{Bb}}$ \\
\hline & 15 & $15.15 \pm 0.72 \mathrm{Cc}$ & $16.62 \pm 1.87^{\mathrm{BC}}$ & $21.88 \pm 0.96$ Ac & $17.15 \pm 1.92 \mathrm{Bc}$ \\
\hline
\end{tabular}

Values are the mean of three replications \pm standard deviation. Different lowercase superscripts in the same column denote the significant difference $(p \leq 0.05)$ due to storage time. Different uppercase superscripts in the same row denote the significant difference $(p \leq 0.05)$ due to different packaging containers.

For color, all samples showed a similar trend of color changing when prolonging the storage time as shown in Table 2. The result revealed that the redness/greenness expressed as $a^{*}$-value did not change throughout 15 months of room temperature storage $(p>0.05)$, which was in the range of 8.11-9.02 at the end of the 15th months. Handayani et al. [16] stated that astaxanthin, which is naturally found as a pigment in shrimp and is used as a raw material, is the source of the red color for a salted shrimp paste product, thus the color of this product is depicted as a reddish yellow color. However, the browner/darker color of the shrimp paste was noted when extending the length of fermentation, then surpassed the red of the product [23]. This was in agreement with the results in this study which exhibited that the decrease in $L^{*}$ - and $b^{*}$-values were obtained in all samples when storage time increased $(p \leq 0.05)$. These changes indicated the development of brown color which was associated well with the increase in browning intensity $\left(\mathrm{A}_{420}\right)$ (Figure 1A). The decrease in $L^{*}$ - and $b^{*}$-value when extended the storage/fermentation time has been noted in many fermented fishery products including fish sauce [24], fermented anchovy sauce [25], or shrimp paste [2], etc. Among all samples, the higher rate of decreasing in $b^{*}$ value was observed in PP and PET, while GJ had the slowest rate during storage ( $p \leq 0.05)$. This was coincidental with the changes in browning intensity $\left(\mathrm{A}_{420}\right)$ (Figure $\left.1 \mathrm{~A}\right)$, indicating that PP and PET containers exhibited the fastest rate of brown color development during storage, compared with other containers. However, this change seems to be desirable since these two samples had the higher color liking scores (Table 3). Thus, it might be inferred that the browner/darker color of salted shrimp paste governed by extended the fermentation period or storage time influences a more preferable color of the product. 

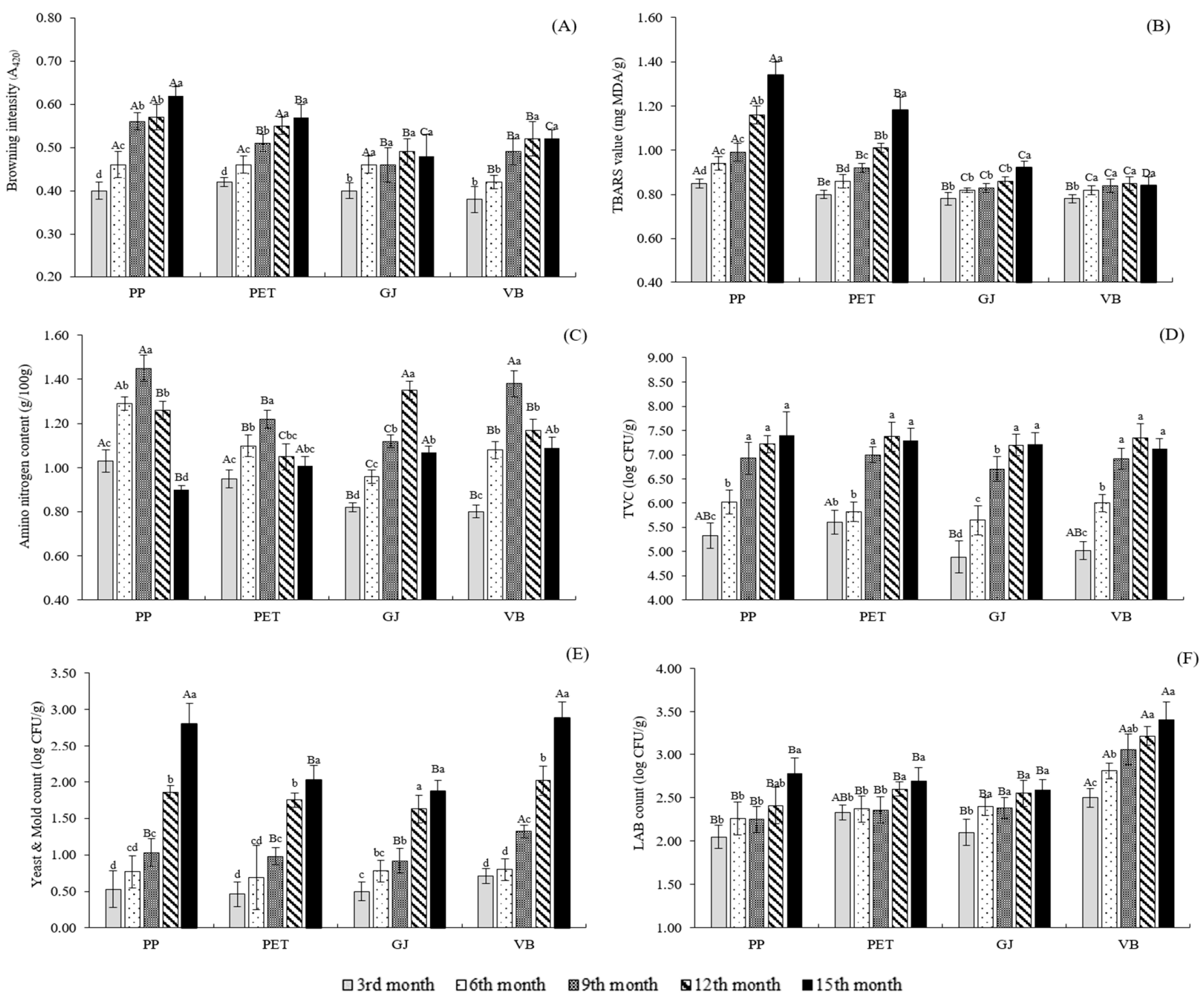

Figure 1. Changes in browning intensity $\left(\mathrm{A}_{420}\right)(\mathrm{A})$, TBARS value $(\mathbf{B})$ and amino nitrogen content (C), TVC (D), yeast and mold count (E) and LAB count (F) of salted shrimp paste stored in various packaging container at room temperature $\left(28 \pm 1{ }^{\circ} \mathrm{C}\right)$. Different lowercase superscripts denote the significant difference $(p \leq 0.05)$ due to storage time. Different uppercase superscripts denote the significant difference $(p \leq 0.05)$ due to different packaging containers. Bars represent the standard deviation from triplicate determination. 
Table 3. Changes in biogenic amines and sensory scores of salted shrimp paste stored in various packaging container at room temperature $\left(28 \pm 1^{\circ} \mathrm{C}\right)$.

\begin{tabular}{|c|c|c|c|c|c|c|c|c|c|}
\hline \multirow{2}{*}{ Parameters } & \multirow{2}{*}{ Day 0} & \multicolumn{2}{|c|}{ PP } & \multicolumn{2}{|c|}{ PET } & \multicolumn{2}{|c|}{ GJ } & \multicolumn{2}{|c|}{ VB } \\
\hline & & M6** & M12 & M6 & M12 & M6 & M12 & M6 & M12 \\
\hline \multicolumn{10}{|l|}{ BAs * } \\
\hline $\begin{array}{l}\text { Tryptamine } \\
\text { (Try) }\end{array}$ & $24.80 \pm 1.82$ & $43.40 \pm 2.35^{\mathrm{Cb}}$ & $93.45 \pm 3.27^{\mathrm{Aa}}$ & $52.65 \pm 2.02^{\mathrm{Bb}}$ & $88.10 \pm 2.59$ Аа & $35.20 \pm 1.04 \mathrm{Db}$ & $68.52 \pm 2.41^{\mathrm{Ba}}$ & $93.44 \pm 1.29$ Аа & $93.44 \pm 1.29 \mathrm{Aa}$ \\
\hline $\begin{array}{l}\text { Phenethylamine } \\
\text { (Phe) }\end{array}$ & ND & ND & $20.85 \pm 2.01 \mathrm{~A}$ & ND & $6.60 \pm 1.99^{\text {В }}$ & ND & ND & ND & ND \\
\hline $\begin{array}{l}\text { Putrescine } \\
\text { (Put) }\end{array}$ & ND & $31.87 \pm 3.19^{\mathrm{Bb}}$ & $89.22 \pm 4.02 \mathrm{Ba}$ & $24.23 \pm 1.97 \mathrm{Cb}$ & $75.10 \pm 2.11^{\mathrm{Ca}}$ & $7.09 \pm 1.57^{\mathrm{Db}}$ & $50.42 \pm 2.02 \mathrm{Da}$ & $103.56 \pm 2.98 \mathrm{Aa}$ & $103.56 \pm 2.98 \mathrm{Aa}$ \\
\hline $\begin{array}{l}\text { Cadaverine } \\
\text { (Cad) }\end{array}$ & $1.17 \pm 0.40$ & $25.51 \pm 2.05^{\mathrm{Bb}}$ & $50.92 \pm 3.44 \mathrm{Aa}$ & $31.70 \pm 2.02 \mathrm{Ab}$ & $43.50 \pm 2.01 \mathrm{Ba}$ & $25.50 \pm 3.02^{\mathrm{Bb}}$ & $40.34 \pm 2.44^{\text {Ва }}$ & $44.42 \pm 2.05^{\mathrm{Ba}}$ & $44.42 \pm 2.05^{\mathrm{Ba}}$ \\
\hline $\begin{array}{l}\text { Histamine } \\
\text { (Him) }\end{array}$ & $21.53 \pm 0.99$ & $34.80 \pm 2.51^{\mathrm{Bb}}$ & $71.38 \pm 5.02^{\mathrm{Ba}}$ & $32.87 \pm 3.41 \mathrm{~B}^{\mathrm{Bb}}$ & $61.61 \pm 1.98 \mathrm{Ca}$ & $27.79 \pm 3.44 \mathrm{Cb}$ & $45.84 \pm 2.59 \mathrm{Da}$ & $48.14 \pm 2.33^{\mathrm{Ab}}$ & $93.14 \pm 2.33$ Аа \\
\hline $\begin{array}{l}\text { Tyramine } \\
\text { (Tyr) }\end{array}$ & ND & $5.16 \pm 0.52^{\mathrm{Bb}}$ & $8.12 \pm 1.03$ Ва & $4.52 \pm 1.11 \mathrm{~B} C$ & $8.41 \pm 0.76^{\text {Ва }}$ & $3.28 \pm 0.40 \mathrm{Cb}$ & $5.44 \pm 1.06 \mathrm{Ca}$ & $17.15 \pm 1.01 \mathrm{Aa}$ & $17.15 \pm 1.01$ Аа \\
\hline $\begin{array}{l}\text { Spermine } \\
(\mathrm{Spm})\end{array}$ & ND & ND & ND & ND & ND & ND & ND & ND & ND \\
\hline $\begin{array}{l}\text { Spermidine } \\
\text { (Spd) }\end{array}$ & ND & ND & ND & ND & ND & ND & ND & ND & ND \\
\hline Total BAs & $47.50 \pm 1.40$ & $140.73 \pm 0.42^{\mathrm{Bb}}$ & $333.94 \pm 4.39$ Ва & $145.97 \pm 6.48^{\mathrm{Bb}}$ & $283.32 \pm 2.18^{\mathrm{Ca}}$ & $98.86 \pm 5.85^{\mathrm{Cb}}$ & $210.56 \pm 5.79 \mathrm{Da}$ & $306.71 \pm 12.23^{\mathrm{Ab}}$ & $351.71 \pm 12.23^{\mathrm{Aa}}$ \\
\hline \multicolumn{10}{|l|}{ Sensory scores } \\
\hline Appearance & $7.04 \pm 0.23$ & $7.76 \pm 0.22^{\mathrm{a}}$ & $6.78 \pm 0.36^{\mathrm{Ab}}$ & $7.68 \pm 0.31^{\mathrm{a}}$ & $6.72 \pm 0.31^{\mathrm{Ab}}$ & $7.34 \pm 0.50^{\mathrm{a}}$ & $6.96 \pm 0.24^{\mathrm{Ab}}$ & $7.44 \pm 0.27^{\mathrm{a}}$ & $5.94 \pm 0.22^{\mathrm{Bb}}$ \\
\hline Color & $6.44 \pm 0.19$ & $7.56 \pm 0.40^{\mathrm{A}}$ & $7.42 \pm 0.44$ & $7.40 \pm 0.33^{\mathrm{A}}$ & $7.46 \pm 0.30$ & $6.90 \pm 0.22^{\mathrm{Bb}}$ & $7.20 \pm 0.29^{a}$ & $7.26 \pm 0.25^{\mathrm{AB}}$ & $7.24 \pm 0.32$ \\
\hline Flavor & $7.18 \pm 0.30$ & $8.22 \pm 0.30 \mathrm{Aa}$ & $6.04 \pm 0.40^{\mathrm{Bb}}$ & $8.03 \pm 0.31 \mathrm{ABa}$ & $6.28 \pm 0.25^{\mathrm{Bb}}$ & $7.66 \pm 0.39 \mathrm{Ba}$ & $7.08 \pm 0.34^{\mathrm{Ab}}$ & $8.26 \pm 0.25 \mathrm{Aa}$ & $5.42 \pm 0.23 \mathrm{Cb}$ \\
\hline Texture & $8.00 \pm 0.22$ & $7.58 \pm 0.28 \mathrm{ABa}$ & $6.16 \pm 0.27^{\mathrm{Bb}}$ & $7.48 \pm 0.40 \mathrm{ABa}$ & $6.28 \pm 0.41 \mathrm{ABb}$ & $8.00 \pm 0.25^{\mathrm{Aa}}$ & $6.60 \pm 0.33^{\mathrm{Ab}}$ & $7.24 \pm 0.32 \mathrm{Ba}$ & $5.66 \pm 0.25^{\mathrm{Cb}}$ \\
\hline Overall & $7.26 \pm 0.35$ & $7.86 \pm 0.23^{\mathrm{Aa}}$ & $6.24 \pm 0.26^{\mathrm{Bb}}$ & $7.78 \pm 0.41 \mathrm{Aa}$ & $6.16 \pm 0.22 \mathrm{Bb}$ & $7.10 \pm 0.29^{B}$ & $7.14 \pm 0.42^{\mathrm{A}}$ & $7.82 \pm 0.31^{\mathrm{Aa}}$ & $5.30 \pm 0.36 \mathrm{Cb}$ \\
\hline
\end{tabular}

${ }^{*}$ Expressed as $\mathrm{mg} / \mathrm{kg}$ sample. ${ }^{* *} \mathrm{M} 6$ and M12 means salted shrimp paste stored for 6 and 12 months, respectively. ND: not detectable. Values are the mean of three replications \pm standard deviation. Different lowercase superscripts denote the significant difference $(p \leq 0.05)$ due to storage time. Different uppercase superscripts denote the significant difference $(p \leq 0.05)$ due to different packaging containers at the same period tests. 


\subsubsection{Changes in Browning Intensity $\left(\mathrm{A}_{420}\right)$}

Measurement of $\mathrm{A}_{420}$ is usually used as the index for the browning development in the final stage of the browning reaction [26]. In this study, the browning intensity $\left(\mathrm{A}_{420}\right)$ of all samples was gradually increased throughout storage time up to 15 months as shown in Figure 1A. Among all samples, PP and PET had the higher $\mathrm{A}_{420}$ than GJ and VB at all period tests $(p \leq 0.05)$. This was in agreement with the faster of decreasing in $L^{*}$-value of PP and PET during storage (Table 2). The dominant of brown color in salted shrimp paste can be described by the appearance of substrates for the Maillard reaction [2]. Those include free amino acids or small peptides, as well as other nitrogenous compounds generated during fermentation/storage, which can provide amino groups for this reaction. While carbohydrate derivatives, that is, glucose-6-phosphate and other substances present in the metabolic pathways could be responsible for carbonyl groups. Moreover, oxidation products, particularly aldehyde, were able to serve as substrate for this reaction [24]. The higher development of brown color in PP and PET was in accordance with the higher TBARS values (Figure 1B), which referred to the higher lipid oxidation occurring in these samples, compared with GJ and VB. Thus, extending the storage time directly influenced the brown color development of salted shrimp paste. Packaging containers/materials plays a profound role in this development, affecting the overall consumer acceptance of the product throughout the storage.

\subsubsection{Changes in TBARS Value}

The TBARS values of salted shrimp paste during storage are given in Figure $1 \mathrm{~B}$. Generally, the increment in TBARS of all samples was observed as the storage time increased $(p \leq 0.05)$. The highest increase in TBARS was observed in PP, followed by PET, particularly after 9 months of storage. At the 15th month of storage, TBARS value of PP and PET reached 1.34 and $1.18 \mathrm{mg}$ MDA/ $\mathrm{kg}$ sample, respectively, while the TBARS value of GJ and VB was still lower than $1.00 \mathrm{mg}$ MDA $/ \mathrm{kg}$ sample. The result indicated that lipid oxidation took place at the higher extent when stored salted shrimp paste in PP and PET containers. The different rate of lipid oxidation occurring in each sample during storage may associated with the $\mathrm{O}_{2}$ availability and permeability of each packaging container, since $\mathrm{O}_{2}$ plays a role as precursor for this mechanism [27]. Massey [22] reported that the $\mathrm{O}_{2}$ permeability of PP is 150-200 Ml/100 sq. inch/day, which higher than PET (10 mL/100 sq. inch/day), associating well with the higher lipid oxidation observed in PP throughout the storage. TBARS were increased at a lower rate when stored in vacuum conditions (VB sample), compared with others, due to the lack of $\mathrm{O}_{2}$ within the container. The higher rate of lipid oxidation may severely compromise the quality of salted shrimp paste, particularly odor/flavor's acceptability, and limits its shelf-life, since the products from lipid oxidation are normally further decomposed into dimers and oligomers, particularly off-flavor volatiles [27].

\subsubsection{Changes in Amino Nitrogen Content}

Changes in the amino nitrogen content of salted shrimp paste during storage are shown in Figure 1C. The amino nitrogen content of PP, PET and VB increased and reached a maximum on the 9th month of storage, while the maximum value of GJ was noted on the 12th month of storage. After that, a slight decline was observed in all samples at the end of storage $(p \leq 0.05)$. The increase in amino nitrogen content during the first period of storage suggested that protein or peptides underwent degradations/decompositions during storage. Conversely, the decrease in amino nitrogen content with a prolonged storage time, particularly after 9 months of storage, may be due to those amino nitrogen further transformed or converted into amines or other nitrogenous compounds as per discussion by Che et al. [9]. In this experiment, the different rate of changes in amino nitrogen content obtained in each sample may indicate the different rate of quality changes caused by packaging materials/containers/conditions, which directly leads to different consumer acceptability to some extent. 


\subsubsection{Changes in Microbial Population}

At 3 months of storage, the highest TVC was found in PET, while the lowest TVC was found in GJ ( $p \leq 0.05$ ) (Figure 1D). Then, there was no significant difference in the TVC of all samples throughout the storage up to 15 months $(p>0.05)$. The TVC of all samples continuously increased and reached the highest values at the 9th month of storage, except the highest TVC of GJ was found at the 12th month of storage. After that, TVC was not significantly changes when extended the storage time up to 15 months $(p>0.05)$. The results may indicate that the GJ container allows slower microbial growth than other containers due to its more inertness, compared with plastic materials. The TVC of salted shrimp paste, which reached the equilibrium of 6.93-7.41 log CFU/g sample during storage, was still in the range of 5.00-8.00 log CFU/g sample, which generally amounts found in fermented foods as reported by Phithakpol [18]. For yeast and mold count, at the first 9 months of storage, the slightly increase as storage time increased was obtained in all samples (Figure 1E). Then, a marked increase in yeast and mold count was depicted when extended the storage time and reached the highest amount when stored for 15 months. At the end of 15 months of storage, yeast and mold count of all samples was 1.87-2.89 log CFU/g sample, which was still in the range of standard regulation $(<3.00 \log \mathrm{CFU} / \mathrm{g}$ sample) [6]. As shown in Figure 1F, the changes in LAB count of PP, PET and GJ were similar throughout the storage, which slightly increased and accounted for 2.59-2.78 log CFU/g sample when stored for 15 months. In contrast, the amount of LAB found in VB was higher than others at all period tests $(p \leq 0.05)$ and reached $>3.00 \log$ CFU /g sample within the 9th month of storage. Normally, LAB is not the predominant bacteria found in shrimp paste [20]. However, high amount of LAB found in VB may because the packaging conditions (vacuum, no air) are suitable for these types of microorganisms. These could lead to a different quality of the products, particularly flavor and odor to some extent, since microorganisms play a key role in the formation of volatiles, particularly in fermented foods [17].

\subsubsection{Changes in Volatile Compounds}

A total of 71 compounds were identified in salted shrimp paste stored in various packaging containers for 15 months, which included eight aldehydes, 14 ketones, 13 alcohols, 14 nitrogen $(\mathrm{N})$-containing compounds, four sulfur (S)-containing compounds, eight hydrocarbons, five esters and five acids as shown in Table 4. Overall, the results indicated that packaging containers/condition induced different changes in volatile profiles during storage, which possibly affect to different product's acceptability to some extent.

Table 4. Changes in volatile compounds of salted shrimp paste stored in various packaging container at room temperature $\left(28 \pm 1^{\circ} \mathrm{C}\right)$.

\begin{tabular}{lccccccccc}
\hline \multirow{2}{*}{ Volatile Compounds } & Day 0 & \multicolumn{2}{c}{ PP } & \multicolumn{2}{c}{ PET } & & GJ & \multicolumn{2}{c}{ VB } \\
\cline { 3 - 9 } & & M6 ** & M12 & M6 & M12 & M6 & M12 & M6 & M12 \\
\hline Aldehydes (8) & & & & & & & & \\
Ethanal (Acetaldehyde) & $0.28 *$ & 1.25 & 0.16 & 1.66 & 0.25 & 3.05 & 1.05 & 0.40 & 0.11 \\
2-methyl-propanal & 2.05 & 0.83 & 0.08 & 0.28 & 0.10 & 1.17 & 0.24 & 2.01 & 0.62 \\
2-methyl-butanal & 4.60 & 1.38 & 0.99 & 0.70 & 0.54 & 0.99 & 0.13 & 3.06 & 4.22 \\
3-methyl-butanal & 6.92 & 4.02 & 2.05 & 3.09 & 0.79 & 10.33 & 4.11 & 1.55 & 0.45 \\
Pentanal & 1.04 & 1.00 & 0.21 & 0.43 & 0.16 & 3.41 & 2.19 & 0.21 & 0.09 \\
2-hexanal & 3.06 & 2.14 & 0.89 & 0.69 & 1.01 & 2.45 & 0.64 & 1.08 & 0.14 \\
2-octenal & 0.69 & 0.27 & ND & 0.11 & ND & 0.21 & 0.09 & 0.12 & 0.48 \\
benzaldehyde & 4.27 & 4.01 & 6.24 & 3.66 & 5.23 & 5.09 & 5.03 & 3.59 & 3.22 \\
Total aldehydes & 22.91 & 14.90 & 10.62 & 10.62 & 8.08 & 26.70 & 13.48 & 12.02 & 9.33 \\
\hline Ketones (14) & & & & & & & & \\
2-propanone & 0.42 & 1.01 & 0.34 & 0.88 & 0.69 & 0.58 & 0.66 & 0.55 & 0.21 \\
Phenyl-2-propanon & 0.36 & 0.63 & 0.07 & 0.78 & 0.94 & 0.26 & 0.50 & 0.32 & 0.08 \\
2,3-butanedione & ND & ND & ND & ND & ND & ND & ND & 0.12 & 1.28 \\
2-butanone & 1.89 & 2.04 & 0.99 & 1.93 & 2.01 & 2.55 & 3.02 & 0.78 & 0.26 \\
\hline
\end{tabular}


Table 4. Cont.

\begin{tabular}{|c|c|c|c|c|c|c|c|c|c|}
\hline \multirow{2}{*}{ Volatile Compounds } & \multirow{2}{*}{ Day 0} & \multicolumn{2}{|c|}{ PP } & \multicolumn{2}{|c|}{ PET } & \multicolumn{2}{|c|}{ GJ } & \multicolumn{2}{|c|}{ VB } \\
\hline & & M6 ** & M12 & M6 & M12 & M6 & M12 & M6 & M12 \\
\hline $\begin{array}{l}\text { 1-(2-aminophenyl)- } \\
\text { ethanone }\end{array}$ & 1.65 & 1.62 & 0.68 & 1.65 & 1.95 & 0.32 & 0.52 & 0.66 & 0.14 \\
\hline 2-pentanone & 2.98 & 5.47 & 3.36 & 4.22 & 4.67 & 4.02 & 3.28 & 2.01 & 1.24 \\
\hline 2-hexanone & 3.95 & 6.28 & 3.02 & 5.08 & 5.12 & 5.55 & 4.99 & 5.05 & 1.88 \\
\hline 1-phenyl-1-hexanone & 0.99 & 1.44 & 1.29 & 1.29 & 1.05 & 0.67 & 0.43 & 1.02 & 1.98 \\
\hline 2-heptanone & 2.18 & 4.02 & 1.99 & 3.66 & 4.22 & 2.02 & 2.45 & 2.67 & 0.93 \\
\hline 6-methyl-5-hepten-2-one & ND & ND & ND & ND & ND & ND & ND & ND & 0.68 \\
\hline 2-octanone & 0.30 & 0.65 & 0.23 & 0.50 & 0.14 & 0.18 & 0.11 & 0.21 & 0.11 \\
\hline 3,5-octadiene-2-one & ND & ND & 0.22 & ND & 0.09 & ND & ND & ND & 0.25 \\
\hline 2-nonanone & ND & ND & ND & ND & ND & ND & ND & ND & 0.43 \\
\hline 2-undecanone & 1.18 & 2.07 & 3.14 & 1.97 & 3.08 & 1.22 & 2.99 & 1.02 & 1.56 \\
\hline Total ketones & 15.90 & 25.23 & 15.33 & 21.96 & 23.96 & 17.37 & 18.95 & 14.41 & 11.03 \\
\hline \multicolumn{10}{|l|}{ Alcohols (13) } \\
\hline 2-butyl-ethanol & ND & ND & 1.06 & ND & ND & ND & ND & 1.02 & 2.23 \\
\hline 2-propanol & 0.22 & ND & ND & ND & ND & ND & ND & 0.12 & 1.06 \\
\hline 2-methyl, 1-propanol & 2.11 & 0.41 & 0.09 & 0.88 & 0.14 & 0.29 & 1.68 & 0.86 & 1.53 \\
\hline 3-methyl-butanol & 1.97 & 0.66 & 1.03 & 1.32 & 2.05 & 0.21 & 2.01 & 1.36 & 4.26 \\
\hline 1-pentanol & 0.16 & ND & 0.53 & ND & 0.12 & ND & ND & ND & ND \\
\hline 1-penten-3-ol & 2.88 & 0.52 & 2.58 & 0.89 & 2.66 & 0.13 & 0.16 & 1.01 & 1.01 \\
\hline 5-methoxy-1-pentanol & ND & ND & ND & ND & ND & ND & ND & ND & 0.52 \\
\hline 1-hexanol & 0.65 & 0.12 & 2.96 & 0.22 & 4.09 & 0.34 & 2.44 & 0.24 & 1.04 \\
\hline 2-ethyl, 1-hexanol & 0.39 & ND & 2.92 & ND & 1.88 & ND & ND & 0.18 & 2.05 \\
\hline 5-methyl-cyclohexanol & ND & ND & 0.58 & ND & 1.02 & ND & ND & ND & 1.28 \\
\hline 1,5-octadiene-3-ol & ND & ND & ND & ND & ND & ND & ND & ND & 2.66 \\
\hline 1-octen-3-ol & 0.72 & 0.24 & 2.03 & 0.56 & 0.37 & 0.60 & 2.35 & 0.38 & 0.24 \\
\hline Phenol & 1.05 & 2.02 & 5.08 & 2.14 & 4.13 & 1.53 & 3.46 & 3.02 & 6.16 \\
\hline Total alcohols & 10.15 & 3.97 & 18.86 & 6.01 & 16.46 & 3.10 & 12.10 & 8.19 & 24.04 \\
\hline \multicolumn{10}{|l|}{$\begin{array}{l}\text { N-containing compounds } \\
\text { (14) }\end{array}$} \\
\hline Trimethyl amine & 6.55 & 2.05 & 0.23 & 3.16 & 1.18 & 7.07 & 2.06 & 6.32 & 4.25 \\
\hline $\begin{array}{l}N, N \text {-dimethyl- } \\
\text { methylamine }\end{array}$ & ND & ND & ND & ND & ND & ND & ND & 2.65 & 1.05 \\
\hline 3-ethyl-4-methyl-pyridine & ND & 1.66 & 1.27 & 1.09 & 0.54 & ND & ND & 3.55 & 1.44 \\
\hline Methyl-pyrazine & 4.02 & 5.25 & 4.99 & 6.01 & 4.32 & 4.22 & 7.13 & 2.08 & 0.99 \\
\hline 2-ehtyl-6-methyl-pyrazine & 1.02 & 2.06 & 1.89 & 2.31 & 1.06 & 1.50 & 2.02 & 3.03 & 1.28 \\
\hline 3-ethyl-5-methyl-pyrazine & 0.43 & 0.61 & 0.71 & 0.56 & 0.29 & 0.26 & 1.55 & 1.52 & 0.77 \\
\hline 2,5-dimethyl-pyrazine & 8.17 & 9.02 & 9.11 & 8.55 & 8.63 & 7.53 & 12.08 & 9.26 & 5.24 \\
\hline 2,6-dimethyl-pyrazine & ND & 1.06 & 0.98 & 1.15 & 0.99 & ND & 1.23 & 2.05 & 0.27 \\
\hline $\begin{array}{l}\text { 3-ethyl-2,5-dimethyl- } \\
\text { pyrazine }\end{array}$ & 5.26 & 7.59 & 6.25 & 7.99 & 5.14 & 6.06 & 7.07 & 6.03 & 4.43 \\
\hline $\begin{array}{l}\text { 2-ethyl-3,5-dimethyl- } \\
\text { pyrazine }\end{array}$ & 3.02 & 3.50 & 4.02 & 3.78 & 3.66 & 3.22 & 3.40 & 1.23 & 1.02 \\
\hline $\begin{array}{l}\text { 2,6-diethyl-3,5- } \\
\text { dimethylpyrazine }\end{array}$ & 0.15 & 0.61 & 0.16 & 0.54 & 0.31 & ND & ND & 1.02 & 0.36 \\
\hline Tetramethylpyrazine & 0.30 & 0.26 & 0.09 & 0.67 & 0.40 & 0.15 & ND & 0.16 & ND \\
\hline 2,3,5-trimethyl-pyrazine & ND & 2.05 & 2.24 & 3.55 & 4.01 & 2.02 & 3.46 & 4.04 & 2.06 \\
\hline Indole & 0.95 & 4.44 & 6.01 & 4.28 & 5.86 & 2.41 & 5.98 & 5.03 & 8.13 \\
\hline $\begin{array}{l}\text { Total N-containing } \\
\text { compounds }\end{array}$ & 29.87 & 40.16 & 37.95 & 43.64 & 36.39 & 34.44 & 45.98 & 47.97 & 31.29 \\
\hline \multicolumn{10}{|l|}{$\begin{array}{l}\text { S-containing compounds } \\
\text { (4) }\end{array}$} \\
\hline Dimethyl-disulfide & 0.89 & 1.25 & 3.55 & 1.63 & 4.02 & 0.92 & 1.62 & 3.60 & 7.79 \\
\hline Dimethyl-trisulfide & 1.45 & 0.89 & 0.46 & 1.01 & 0.40 & 0.99 & 0.66 & 0.56 & 0.28 \\
\hline
\end{tabular}


Table 4. Cont.

\begin{tabular}{|c|c|c|c|c|c|c|c|c|c|}
\hline \multirow{2}{*}{ Volatile Compounds } & \multirow{2}{*}{ Day 0} & \multicolumn{2}{|c|}{ PP } & \multicolumn{2}{|c|}{ PET } & \multicolumn{2}{|c|}{ GJ } & \multicolumn{2}{|c|}{ VB } \\
\hline & & M6 ** & M12 & M6 & M12 & M6 & M12 & M6 & M12 \\
\hline \multirow{3}{*}{$\begin{array}{l}\text { Dimethyl-tetrasulfide } \\
\text { Methanethiol } \\
\text { Total S-containing } \\
\text { compounds }\end{array}$} & 0.36 & 0.50 & 1.02 & 0.85 & 0.81 & 0.23 & 0.45 & 0.48 & 2.45 \\
\hline & 0.41 & 0.38 & 0.99 & 0.54 & 0.88 & 0.16 & 0.37 & 1.43 & 3.01 \\
\hline & 3.11 & 3.02 & 6.02 & 4.03 & 6.11 & 2.30 & 3.10 & 6.07 & 13.53 \\
\hline \multicolumn{10}{|l|}{ Hydrocarbons (8) } \\
\hline 3-tetradecene & 0.61 & 0.21 & 1.68 & 0.34 & 1.28 & 0.59 & 0.23 & 0.11 & 0.07 \\
\hline 2,3-butanediene & ND & ND & 0.54 & ND & 0.52 & ND & ND & 0.36 & 1.44 \\
\hline 1-pentadecene & ND & 0.16 & 1.02 & 0.10 & 0.96 & ND & 0.24 & ND & 0.22 \\
\hline Hexadecane & 2.23 & 1.41 & 0.91 & 1.35 & 0.54 & 2.08 & 1.05 & 0.24 & 0.07 \\
\hline 2,6-cyclohexadiene & 1.31 & 0.63 & 0.45 & 0.65 & 0.40 & 1.22 & 0.55 & 0.20 & 0.13 \\
\hline Decane & ND & ND & ND & ND & ND & ND & ND & 0.45 & 0.16 \\
\hline 1,4-octadiene & ND & 0.19 & 1.02 & 0.20 & 0.85 & ND & ND & 0.62 & 1.01 \\
\hline 2-octene & 0.42 & 0.46 & 0.68 & 0.39 & 0.62 & 0.77 & 1.07 & 0.18 & 0.22 \\
\hline Total hydrocarbons & 4.57 & 3.06 & 6.30 & 3.03 & 5.17 & 4.66 & 3.14 & 2.16 & 3.32 \\
\hline \multicolumn{10}{|l|}{ Esters (5) } \\
\hline 2-Methylbutyl acetate & 1.09 & 0.45 & 0.21 & 0.56 & 0.14 & 0.60 & 0.62 & 0.26 & 0.23 \\
\hline Ethyl buterate & 2.52 & 3.69 & 1.09 & 3.71 & 1.45 & 2.66 & 0.14 & 1.93 & 0.94 \\
\hline $\begin{array}{l}\text { 2-Methylbutyl-3- } \\
\text { methylbutanoate }\end{array}$ & ND & 0.50 & 0.22 & 0.33 & 0.13 & 0.12 & 0.07 & ND & ND \\
\hline Isopropyl myristate & ND & 0.22 & 0.23 & 0.18 & 0.19 & ND & ND & ND & ND \\
\hline Methyl palmitate & 1.44 & 1.19 & 0.24 & 1.25 & 0.08 & 1.01 & 0.12 & 0.23 & 0.09 \\
\hline Total esters & 5.05 & 6.05 & 1.99 & 6.03 & 1.99 & 4.39 & 0.95 & 2.42 & 1.26 \\
\hline \multicolumn{10}{|l|}{ Acids (5) } \\
\hline Acetic acid & 1.01 & 0.18 & ND & 0.21 & 0.09 & 0.49 & 0.22 & 0.42 & 0.08 \\
\hline Propanoic acid & 3.66 & 1.07 & 0.68 & 1.99 & 0.42 & 3.01 & 1.02 & 1.50 & 1.03 \\
\hline Butanoic acid & 3.02 & 1.33 & 2.02 & 1.52 & 1.05 & 2.68 & 0.64 & 2.55 & 2.55 \\
\hline 2-methyl-butanoic acid & 0.65 & 0.42 & 0.16 & 0.40 & 0.08 & 0.73 & 0.16 & 0.70 & 0.94 \\
\hline Isobutyric acid & ND & ND & ND & ND & ND & ND & ND & 1.01 & 1.54 \\
\hline Total acids & 8.34 & 3.00 & 2.86 & 4.12 & 1.64 & 6.91 & 2.04 & 6.18 & 6.14 \\
\hline Total peak abundance & 99.90 & 99.39 & 99.93 & 99.44 & 99.80 & 99.87 & 99.74 & 99.42 & 99.94 \\
\hline
\end{tabular}

Abundance of aldehydes, that is, 2-methyl-butanal, 3-methyl-butanal, 2-hexanal, benzaldehyde and so forth, of fresh shrimp paste (day 0) was $22.91 \%$. These compounds were maximal at the beginning of storage and then decreased with storage time in all samples. Aldehydes can be generated by lipid oxidation and degradation during fermentation [17]. Aldehydes are considered to enhance the flavor quality which associated with sweety, fruity, nutty and caramel-like odors [28]. Thus, the decrease in aldehydes when stored for 15 months may associated with the decrease in flavor-liking scores, leading to the decrease in product's acceptability (Table 3 ). Ketones were found at $15.90 \%$ in salted shrimp paste before storage (day 0) including 2-propanone, 2-pentanone, 2-hexanone, and so forth. Most of them still remained after 12 months of storage. In general, both aldehydes and ketones were more likely generated from lipid oxidation during fermentation [19]. Among all the samples, PP and PET seem to have the higher ketones, compared with GJ and VB. The results were in agreement with the higher lipid oxidation occurring in these two samples as indicated by the higher TBARS value (Figure 1B). Moreover, it has been noted that some ketones were generated during storage and were found only in the VB sample. Those included 2,3-butanedione, 6-methyl-5-hepten-2-one, 3,5-octadiene-2-one and 2-nonanone. These compounds may lead the flavor/odor of VB to differ from other samples to some extent. Alcohols were also found at a low amount $(10.15 \%)$ at the beginning of storage. The decrease in alcohols was found when stored for 6 months and then increased when stored for 12 months in all samples. At the end of 12 months, the marked highest alcohols 
were obtained in VB, accounting for $24.04 \%$, compared with others. The higher alcohols when shrimp were stored in vacuum conditions may be associated with the higher LAB (Figure 1F). Helinck et al. [29] reported that some lactic acid bacteria could produce a large amount of 3-methylbutanol from phenylalanine, valine and leucine, which are amino acid found in fresh shrimp used as raw material. Phenol was found in fresh shrimp paste (day 0) with low intensity $(1.05 \%)$ and then continuously increased as storage time increased in all samples. This compound may relate with the decrease in flavor-liking score when extended the storage time since it was reported to give an undesirable aroma in seafood [17].

Among the identified volatiles, $\mathrm{N}$-containing compounds were predominant volatiles in all samples throughout the storage up to 15 months, which are mainly classified into two types, amines and pyrazines. At day 0, salted shrimp paste contained $\mathrm{N}$-containing compounds of $29.87 \%$. These compounds were intensively increased to $34.44 \%-43.64 \%$ at 6 months of storage. Trimethylamine was the major volatile found at the beginning of storage (day 0), which was formed by the microbial reduction of trimethylamine oxide [28], then gradually declined when extended the storage time. Pyrazine derivatives, including 2-ehtyl-6-methyl-pyrazine, 2,5-dimethyl-pyrazine, 3-ethyl-2,5-dimethyl-pyrazine, and so forth., as well as indole of all samples increased as storage time increased. Pyrazines are generated via Maillard reaction through the Strecker degradation as various nitrogen sources including amino acids as a precursor and metabolic activities of microorganisms during fermentation [30]. These compounds contribute to desirable flavors and aromas of various fermented foods including shrimp paste [17], fish miso [31] and vegetarian soybean paste [32]. At the end of 12 months of storage, the highest $\mathrm{N}$-containing compounds was found in GJ (45.98\%), while the lowest was found in VB (31.29\%), associating well with the highest and lowest flavor-liking score of GJ and VB, respectively (Table 3). The results help to confirm that these $\mathrm{N}$-containing compounds plays a key role for desirable flavor of this product.

Four S-containing compounds were found in shrimp paste at day 0 and still remained throughout the storage time of 12 months. Those included dimethyl-disulfide, dimethyltrisulfide, dimethyl-tetrasulfide and methanethiol. The highest S-containing compounds were found in VB (13.53\%), while the lowest was noted in GJ $(3.10 \%)$ when stored for 12 months. The S-containing compounds are considered to be enzymatically produced in seafood from methionine and cysteine [33]. Song et al. [34] reported that sulfides, such as dimethyl disulfide and dimethyl trisulfide, act as aroma compounds and are the precursors for reactions leading to the production of more complex aroma compounds, which mostly responsible for undesirable odor of fermented products. Some hydrocarbons including 3-tetradecene, hexadecane and 2-octene, and so forth was found in shrimp paste at the low amount throughout the storage (almost 5\%). However, due to their higher odor threshold, hydrocarbons contribute little to the overall flavor of foods [35]. Five types of ester compounds were detected in fresh shrimp paste (day 0), accounting for 5.05\% such as 2-methylbutyl acetate, methyl palmitate, and so forth. In general, most of the esters were produced in the middle and late stages of fermentation [9]. These compounds contributed to the distinct flavor of the fermented shrimp paste [28]. The decline of ester compounds to $0.95 \%-1.26 \%$ was found when stored for up to 12 months. This may reduce some desirable flavor of the product due to the storage time increasing. Additionally, four acids were detected in shrimp paste and still remained throughout the 15 months of storage. Those included acetic acid, propanoic acid, butanoic acid and 2-methyl-butanoic acid. While isobutyric acid was found only in VB in both when stored for 6 and 12 months. Kubota et al. [36] reported that butanoic acid gives the cheesy notes in roasted shrimp. Kleekayai et al. [28] reported that 2-methyl-butanoic acid provides a pungent butter fat-like odor but not as unpleasant for shrimp paste.

\subsubsection{Changes in BAs}

The total BA contents of shrimp paste at day 0 was $47.50 \mathrm{mg} / \mathrm{kg}$ sample (Table 3 ). Only three kinds of BAs were observed in the fresh sample including tryptamine, cadaverine and 
histamine, accounting for $24.80,1.17$ and $21.53 \mathrm{mg} / \mathrm{kg}$ sample, respectively. The result was in agreement with $\mathrm{Li}$ et al. [37] who stated that tryptamine and histamine were considered as the predominant BAs in the commercial Huanghua shrimp pastes. The total BAs of all samples intensively increased as storage time increased $(p \leq 0.05)$. Among all samples, the highest total BAs was found in VB, while the lowest total BAs was found in GJ at all period tests $(p \leq 0.05)$. In general, the type and amount of BAs formed during storage depends on many factors such as shrimp species, microbial flora, packaging, temperature, and so forth [37]. In this experiment, shrimp paste stored in different packaging containers, which have different water and gas permeability, may lead to the different formation and accumulation of BAs. Histamine, which was one of the predominant BAs found in this product, has been known as a toxic compound to human health. This toxicity is intensified by the presence of other amines such as putrescine and cadaverine [38]. The content of histamine of all samples was in a range of $27.79-48.14 \mathrm{mg} / \mathrm{kg}$ sample when stored for 6 months, which is below $50 \mathrm{mg} / \mathrm{kg}$, indicating the safe level in seafood products set by USFDA [39]. The histamine content of all samples (except GJ) exceeded the safety level when stored for 12 months, indicating the safety for health. However, histamine below 200 $\mathrm{mg} / \mathrm{kg}$ is considered as an acceptable quantity for fermented products [40]. Spermine and spermidine were not detected in all samples throughout the storage for 12 months. While putrescine and tyramine were not detected in shrimp paste at the beginning of storage but these BAs were generated during storage and become dominant when extending the storage time. Putrescine has also been proposed as spoilage indices and affected to cause undesirable odor in fish and fish products [37]. The marked increase of putrescine as storage time increased, particularly in the VB sample, may be associated with the decrease in flavor-liking scores (Table 3). The results suggested that BAs occurring in the product can both affect the quality and safety aspects.

\subsubsection{Changes in Sensory Scores}

Salted shrimp paste at the beginning of storage received scores on all attributes including appearance, flavor, texture and overall likeness higher than 7.00, indicating the high acceptability of the product (Table 3). However, the fresh sample received a score of 6.44 for color-likeness, which is quite low compared with the other attributes. This may be due to the development of the brown color not being complete at the beginning of storage. A relationship between the color-likeness and browning development of the shrimp paste product was observed. It was found that the color-likeness score increased as storage time increased in all samples, correlating well with the increase in browning intensity of the product (Figure 1A). This also led to the increase in appearance-likeness score. Generally, the color of shrimp paste is the one factor affecting the overall consumer acceptance, and the brown color is a preferable quality attribute of this product as mentioned by Pongsetkul et al. [2]. Not only color-likeness score, but other sensory scores of all samples also increased when stored for 6 months, compared with scores on day 0 . This indicated the development of desirable characteristics of shrimp paste during storage. The increase in flavor-likeness scores may be associated with the increase in volatiles, particularly $\mathrm{N}$-containing compounds which has been noted as a fragrant/unique aroma for this product [17]. However, the marked decrease of flavor-likeness scores were observed in all samples when extending the storage time to 12 months. This may describe the high formation of some degradable products when extending the storage time such as BAs, TBARS, and so forth, which may deviate the unique and desirable flavor of this product. At the 12th month of storage, VB had the lowest flavor-likeness scores (5.42), compared with others $(p \leq 0.05)$, associating with the higher BAs and unique volatiles found in this product. The result suggested that keeping shrimp paste in the vacuum condition may lead to the different/unique flavor, reducing the desirable characteristics to some extent. This reason was confirmed by the lowest overall-likeness scores of VB (5.30) as well. Moreover, the texture-likeness scores of all samples decreased when stored for 12 months $(p \leq 0.05)$. This may relate well with the increase in $\mathrm{a}_{\mathrm{w}}$, showing that the shrimp paste became watery 
when extending the storage time. This phenomenon was not a desirable characteristic assessed by consumers.

\subsubsection{Principle Component Analysis (PCA)}

The relationship between quality attributes of salted shrimp paste stored in different packaging containers and consumer acceptability as indicated by sensory scores using PCA were evaluated. Figure 2A demonstrated the PCA of shrimp paste stored for 6 months, which the first two principal components could be described as $83.67 \%$ of the variations in the dataset. From the loadings of PC1 (45.65\%), samples placed to the right along PC1 including PP and PET were characterized by a higher intensity of N-containing compound, associated with the higher flavor and overall-likeness scores. Conversely, samples placed to the left along PC1 (VB and GJ) were described by the higher content of other volatiles including S-containing compounds, alcohols, aldehydes, ketones and acid. This could be confirmed that PP and PET were the most appropriate containers for shrimp paste storage when stored for 6 months. From Figure 2B, the PC1 separates GJ, which placed to the right along PC1, from other samples which placed to the left along PC1 when stored salted shrimp paste for 12 months. It was observed that $\mathrm{N}$-containing compounds still had the strong relationship with flavor-likeness and overall-likeness scores. However, GJ exhibited more relationship with those characteristics when stored for 12 months instead of PP and PET. Moreover, browning index, associated with the color-likeness and appearancelikeness score, was also obtained in GJ. In contrast, PP and PET at the 12th month of storage had a long distance from those desirable characteristics, compared with the 6th month of storage. The result indicated that GJ got the highest acceptability, compared with others when prolonged the shelf-life to 12 months. In addition, VB exhibited strong relationship with S-containing compounds and BAs at all period tests, inferring that vacuum conditions may lead to the different microbial profiles and the formation of those undesirable characteristics, which affected the lower sensory acceptability, compared with storage in the aerobic condition.

\subsubsection{Inorganic Contaminants and Pathogens of Salted Shrimp Paste after 15 Months} of Storage

$\mathrm{Hg}$ and $\mathrm{Cd}$, which were found at the beginning of storage, still existed at the end of 15 months of storage as shown in Table 5. However, those contaminants were obtained lower the safety limitation $(<0.5 \mathrm{mg} / \mathrm{kg}$ for $\mathrm{Hg}$ and $<1.0 \mathrm{mg} / \mathrm{kg}$ for Cd) as regulated by TCPS [6]. There was no $\mathrm{Pb}$ and As found in this product throughout the storage. For pathogens, only Salmonella spp. was not detected in all samples. The amount of other pathogens including $S$. aureus, B. cereus, C. perfringens and E. coli increased during storage but within the limited level regulated by the product standard [6]. Thus, the results help to confirm that all samples still had the acceptability of safety aspects based on their standard even when stored for 15 months. However, each sample had a different rate of quality changing due to the different packaging container/condition, which affect the different consumer acceptability as mentioned before.

Table 5. Inorganic contaminants and pathogens of salted shrimp paste at 15 th month of room temperature $\left(28 \pm 1{ }^{\circ} \mathrm{C}\right)$ storage.

\begin{tabular}{lcccc}
\hline Parameters & PP & PET & GJ & VB \\
\hline Inorganic contaminants & & & & ND \\
$\mathrm{Pb}(\mathrm{mg} / \mathrm{kg})$ & $\mathrm{ND}$ & $\mathrm{ND}$ & $\mathrm{ND}$ & $\mathrm{ND}$ \\
$\mathrm{As}(\mathrm{mg} / \mathrm{kg})$ & $\mathrm{ND}$ & $\mathrm{ND}$ & $0.28 \pm 0.10$ & $0.30 \pm 0.11$ \\
$\mathrm{Hg}(\mathrm{mg} / \mathrm{kg})$ & $0.44 \pm 0.13$ & $0.18 \pm 0.05$ & $0.16 \pm 0.04$ & $0.31 \pm 0.15$ \\
$\mathrm{Cd}(\mathrm{mg} / \mathrm{kg})$ & $0.20 \pm 0.04$ & $0.29 \pm 0.08$ & & \\
\hline
\end{tabular}


Table 5. Cont.

\begin{tabular}{lcccc}
\hline Parameters & PP & PET & GJ & VB \\
\hline Pathogen * & & & & ND \\
Salmonella spp. & ND & ND & 55 & ND \\
S. aureus & 76 & 50 & 86 & 25 \\
B. cereus & 109 & 80 & 70 & 112 \\
C. perfringens & 15 & 28 & 50 & 65 \\
E. coli & 110 & 108 & & \\
\hline
\end{tabular}

${ }^{*}$ Expressed as $\mathrm{CFU} / \mathrm{g}$. Values are the mean of three replications \pm standard deviation. ND: Not detectable.

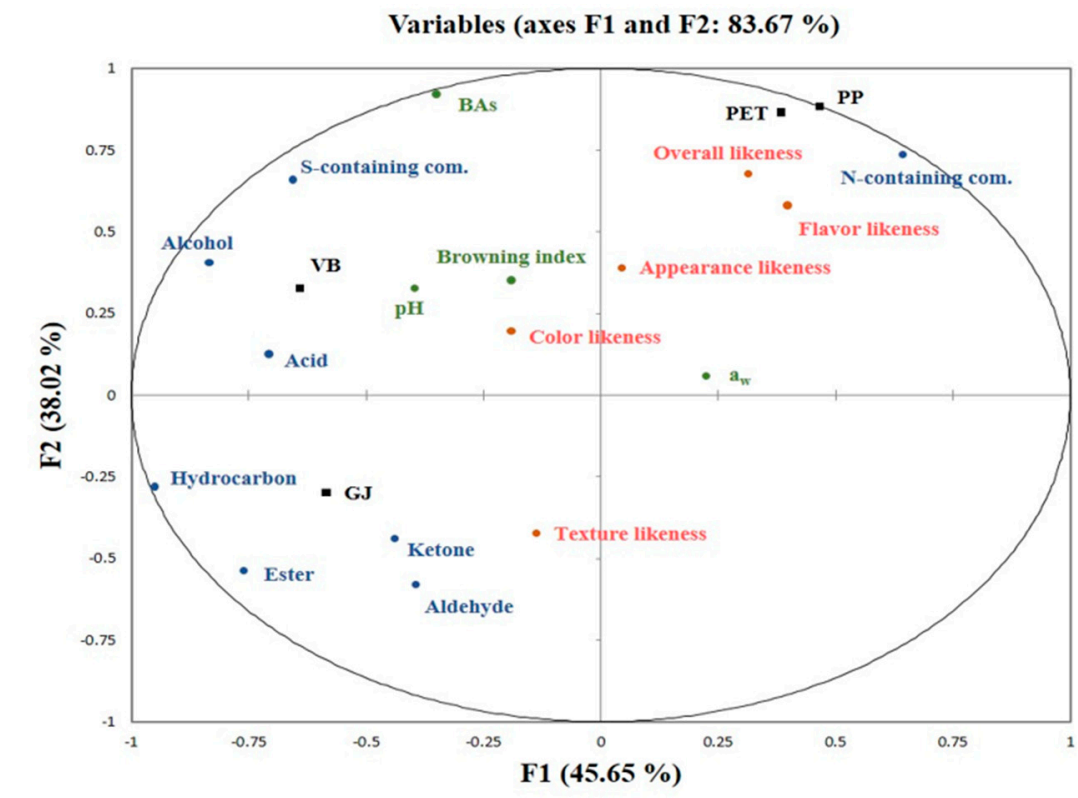

(A)

(B)

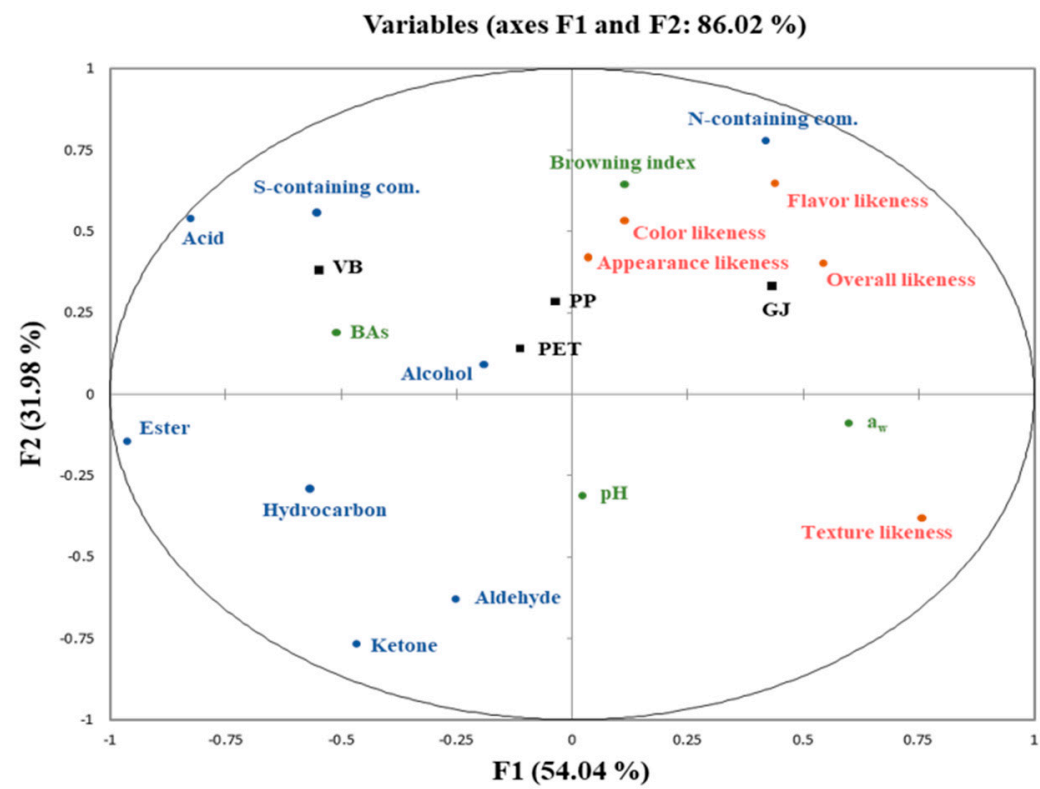

Figure 2. PCA score (samples, black color) and loading (some quality parameters (green color), groups of volatile compounds (blue color) and sensory scores (orange color)) plots of salted shrimp paste stored in different packaging containers for 6 (A) and 12 (B) months of room temperature $\left(28 \pm 1{ }^{\circ} \mathrm{C}\right)$. 


\section{Conclusions}

A different rate of changes in physical, chemical and microbiological characteristics of salted shrimp paste stored in different packaging containers was detected. It was observed that the product's quality was improved during storage as indicated by the highest overalllikeness scores when stored for 6 months. However, further changes in all compositions when extending the storage time can diminish its desirable quality, particularly flavor, leading to lowering consumer acceptability. Among all types of packaging, GJ seem to have the lower rate of quality changing than others, thus having the most potential to preserve original product's quality during storage. In contrast, salted shrimp paste having vacuum storage (VB) exhibited unique volatile and microbial profiles, which lowered the consumer's acceptability, thus this condition may not be suitable for storage of this product.

Author Contributions: Conceptualization, J.P., S.B. and P.B.; methodology, J.P.; validation, J.P.; formal analysis, J.P.; investigation, J.P. and P.B.; resources, J.P., S.B. and P.B.; data curation, J.P.; writingoriginal draft preparation, J.P.; writing - review and editing, J.P. and S.B.; supervision, S.B.; funding acquisition, S.B. All authors have read and agreed to the published version of the manuscript.

Funding: This research was funded by National Research Council of Thailand (NRCT, Research Grants for Talented Young Researchers (2021), grant no. N41A640118).

Institutional Review Board Statement: Not applicable.

Informed Consent Statement: Not applicable.

Data Availability Statement: Not applicable.

Conflicts of Interest: The authors declare no conflict of interest.

\section{References}

1. Hajeb, P.; Jinap, S. Umami taste components and their sources in Asian foods. Crit. Rev. Food Sci. Nutr. 2015, 55, 778-791. [CrossRef] [PubMed]

2. Pongsetkul, J.; Benjakul, S.; Vongkamjan, K.; Sumpavapol, P.; Osako, K.; Faithong, N. Changes in volatile compounds, ATP related compounds and antioxidative properties of Kapi, produced from Acetes vulgaris, during processing and fermentation. Food Biosci. 2017, 19, 49-56. [CrossRef]

3. Pongsetkul, J.; Benjakul, S.; Sumpavapol, P.; Kazufumi, O.; Faithong, N. Chemical composition and physical properties of salted shrimp paste (Kapi) produced in Thailand. Int. Aquat. Res. 2014, 6, 155-166. [CrossRef]

4. Fahrudin, F. Innovative Packaging of Shrimp Paste (Belacan). Academia. 2019. Available online: https://www.academia.edu/42 838769/INNOVATIVE_PACKAGING_OF_SHRIMP_PASTE_BELACAN (accessed on 16 December 2021).

5. Ali, M.; Kusnadi, J.; Aulanniam, A.; Yunianta, Y. Amino acids, fatty acids and volatile compounds of terasi udang, an Indo-nesian shrimp paste, during fermentation. AACL Bioflux. 2020, 13, 938-950.

6. TCPS. Thai Community Product Standard No. TCPS 61/2018: Kapi (Shrimp Paste); Thai Industrial Standards Institute: Bangkok, Thailand, 2018.

7. AOAC. Official Method of Analysis; Association of Official Chemists: Gaithersberg, MA, USA, 2000.

8. Nirmal, N.P.; Benjakul, S. Effect of ferulic acid on inhibition of polyphenoloxidase and quality changes of Pacific white shrimp (Litopenaeus vannamei) during iced storage. Food Chem. 2009, 116, 323-331. [CrossRef]

9. Che, H.; Yu, J.; Sun, J.; Lu, K.; Xie, W. Bacterial composition changes and volatile compounds during the fermentation of shrimp paste: Dynamic changes of microbial communities and flavor composition. Food Biosci. 2021, 43, 101169. [CrossRef]

10. Morgano, M.A.; Rabonato, L.C.; Milani, R.F.; Miyagusku, L.; Balian, S.C. Assessment of trace elements in fishes of Japanese foods marketed in São Paulo (Brazil). Food Control 2011, 22, 778-785. [CrossRef]

11. BAM. Aerobic plate count. In Bacteriological Analytical Manual; Bryce, J., Ed.; U.S. Food and Drug Administration, E-Con Pub-lishing: New York, NY, USA, 2001; pp. 53-67.

12. Sang, X.; Li, K.; Zhu, Y.; Ma, X.; Hao, H.; Bi, J.; Zhang, G.; Hou, H. The impact of microbial diversity on biogenic amines formation in grasshopper sub shrimp paste during the fermentation. Front. Microbiol. 2020, 11, 1-13. [CrossRef]

13. Fennema, O.R. Water and ice. In Food Chemistry; Fennema, O.R., Ed.; Marcel Dekker: New York, NY, USA, 1996; pp. 17-94.

14. Goulas, A.E.; Kontominas, M.G. Effect of salting and smoking-method on the keeping quality of chub mackerel (Scomber ja-ponicus): Biochemical and sensory attributes. Food Chem. 2005, 93, 511-520. [CrossRef]

15. Cho, S.D.; Kim, G.H. Changes of quality characteristics of salt-fermented shrimp prepared with various salts. Korean J. Food Nutr 2010, 23, 291-298.

16. Handayani, B.R.; Ariyana, Z.M.D.; Amaro, R.M.; Ulfa, L.R. Quality Profiles of the Traditional Shrimp Paste of Lombok. In IOP Conference Series: Earth and Environmental Science; IOP Publishing: Bristol, UK, 2021; Volume 913, p. 012033. 
17. Cha, Y.J.; Cadwallader, K.R. Volatile compounds in salt-fermented fish and shrimp pastes. J. Food Sci. 1995, 60, 19-27. [CrossRef]

18. Phithakpol, B. Fish fermentation technology in Thailand. In Fish Fermentation Technology, 4th ed.; Steinkraus, K.H., Reilly, P.J., Eds.; United Nation University Press: Tokyo, Japan, 1993; pp. 155-166.

19. Pongsetkul, J.; Benjakul, S.; Vongkamjan, K.; Sumpavapol, P.; Osako, K.; Faithong, N. Microbiological and chemical changes of shrimp Acetes vulgaris during Kapi production. J. Food Sci. Tech. 2017, 54, 3473-3482. [CrossRef] [PubMed]

20. Nakamura, A.; Kondo, A.; Takahashi, H.; Keeratipibul, S.; Kuda, T.; Kimura, B. Microbiological safety and microbiota of Kapi, Thai traditional fermented shrimp paste, from different sources. LWT-Food Sci. Technol. 2022, 154, 112763. [CrossRef]

21. Robertson, G.L. Food Packaging and Shelf Life: A Practical Guide; CRC Press: Boca Raton, FL, USA, 2010.

22. Massey, L.K. Permeability Properties of Plastics and Elastomers: A Guide to Packaging and Barrier Materials, 2nd ed.; William Andrew Publishing: Norwich, NY, USA, 2003.

23. Ulya, S.; Ria, D.S. The use of Penaeus monodon shrimp head waste for terasi product the study of salt addition and fermentation time. J. Rekapangan 2016, 10, 67-72.

24. Dissaraphong, S.; Benjakul, S.; Visessanguan, W.; Kishimura, H. The influence of storage conditions of tuna viscera before fermentation on the chemical, physical and microbiological changes in fish sauce during fermentation. Bioresour. Technol. 2006, 96, 2030-2040. [CrossRef] [PubMed]

25. Kim, J.H.; Ahn, H.J.; Yook, H.S.; Kim, K.S.; Rhee, M.S.; Ryu, G.H.; Byun, M.W. Colour, flavour, and sensory characteristics of gamma-irradiated salted and fermented anchovy sauce. Radiat. Phys. Chem. 2004, 69, 179-187. [CrossRef]

26. Ajandouz, E.H.; Tchiakpe, L.S.; Ore, F.D.; Benajiba, A.; Puigserver, A. Effects of pH on caramelization and Maillard reaction kinetics in fructose-lysine model systems. J. Food Sci. 2001, 66, 926-931. [CrossRef]

27. Shahidi, F. Indicators for evaluation of lipid oxidation and off-flavor development in food. In Food Flavors: Formation, Analysis and Packaging Influences; Contis, E.T., Ho, C.-T., Mussinan, C.J., Parliment, T.H., Shahidi, F., Spanier, F.S., Eds.; Elsevier: Amsterdam, The Netherlands, 1998; Volume 40, pp. 55-68.

28. Kleekayai, T.; Pinitklang, S.; Laohakunjit, N.; Suntornsuk, W. Volatile components and sensory characteristics of Thai tradi-tional fermented shrimp pastes during fermentation periods. J. Food Sci. Technol. 2016, 53, 1399-1410. [CrossRef]

29. Helinck, S.; Bars, D.L.; Moreau, D.; Yvon, M. Ability of thermophilic lactic acid bacteria to produce aroma compounds from amino acids. Appl. Environ. Microbiol. 2004, 70, 3855-3861. [CrossRef]

30. Labuda, I. Flavor compounds. In Encyclopedia of Microbiology, 3rd ed.; Schaechter, M., Ed.; Academic: San Diego, CA, USA, 2009; pp. 305-320.

31. Giri, A.; Osako, K.; Ohshima, T. SPME technique for analyzing headspace volatiles in fish Miso, a Japanese fish meat-based fermented product. Biosci. Biotechnol. Biochem. 2010, 74, 1770-1776. [CrossRef]

32. Wittanalai, S.; Rakariyatham, N.; Deming, R.L. Volatile compounds of vegetarian soybean kapi, a fermented Thai food con-diment. Afr. J. Biotechnol. 2011, 10, 821-830.

33. Varlet, V.; Fernandez, X. Sulfur-containing volatile compounds in seafood: Occurrence, odorant properties and mechanisms of formation. Food Sci. Technol. Int. 2010, 16, 463-503. [CrossRef] [PubMed]

34. Song, S.; Tang, Q.; Fan, L.; Xu, X.; Song, Z.; Hayat, K. Identification of pork flavour precursors from enzyme-treated lard using Maillard model system assessed by GC-MS and partial least squares regression. Meat Sci. 2017, 124, 15-24. [CrossRef] [PubMed]

35. Yu, J.; Lu, K.; Zi, J.; Yang, X.; Xie, W. Characterization of aroma profiles and aroma-active compounds in high-salt and low-salt shrimp paste by molecular sensory science. Food Biosci. 2022, 45, 101470. [CrossRef]

36. Kubota, K.; Shijimaya, H.; Kobayashi, A. Volatile components of roasted shrimp. Agric. Biol. Chem. 1986, 50, 2867-2873. [CrossRef]

37. Li, W.; Lu, H.; He, Z.; Sang, Y.; Sun, J. Quality characteristics and bacterial community of a Chinese salt-fermented shrimp paste. LWT-J. Food Sci. Technol. 2021, 136, 110358. [CrossRef]

38. Wu, X.H.; Geng, X.J.; Zhang, J.X.; Sang, Y.X.; Sun, J.L. Study on microbiological and physicochemical properties of Huanghua shrimp paste. Food Res. Develop. 2019, 40, 75-81.

39. FDA USA. Fish and Fishery Products Hazards and Controls Guidance, 3rd ed.; Retrieved on 21 November 2021 from FDA website; DIANE Publishing: Washington, DC, USA, 2001.

40. EU. Commission Regulation (EC) No 2073/2005 of 15 November 2005. On microbiological criteria for foodstuffs. Off. J. Eur. Union 2005, 338, 1-25. 